\title{
CONSOLIDATION AND REBOUND CHARACTERISTICS OF EXPANSIVE SOIL BY USING LIME AND BAGASSE ASH
}

\author{
A.T.Manikandan ${ }^{1}$, M.Moganraj ${ }^{2}$ \\ ${ }^{I}$ Final Year Post Graduate Student in Geotechnical Engineering, Civil Engineering Department, SRM University, \\ Tamilnadu, India \\ ${ }^{2}$ Asst. Professor, Civil Engineering Department, SRM University, Tamilnadu, India
}

\begin{abstract}
In this paper, the test results such as index properties, proctor compaction, unconfined compression strength, cationic exchange capacity obtained on expansive clays mixed at different proportions of Bagasse ash $(2 \%, 4 \%, 6 \%)$ and hydrated lime $(1 \%, 2 \%, 3 \%)$ are mixed into 9 mixes, which were presented and discussed along with the consolidation behaviour of the soil. From the results, it is observed that at optimum mixes $3 L+6 B, 3 L+2 B, 2 L+2 B, 3 L+4 B$, the swelling of expansive clay is almost controlled and also noticed that there is a marked improvement in the strength of soil and change of molecular structure. The combination of Bagasse ash and hydrated lime is more effective than the addition of Bagasse ash alone to the expansive soil in controlling the consolidation characteristics. All the test results with clear reasons for increment / decrement in values are explained in this paper.
\end{abstract}

Keywords: Bagasse Ash, Lime, Index Properties, Strength, Consolidation Behaviour, Molecular Structure.

\section{INTRODUCTION}

Industrial development in India has necessitated construction of infrastructure facilities such as highways, airports seaports and residential buildings. There is a need to select good soil conditions for proper safety consideration of all these projects. In India, almost 51.8 million hectares of soil are expansive in nature. Several research works are being carried out to study the behavior of expansive soil, which says that structures , when build over such expansive soil are subjected to serious threat due to its alternative swelling and shrinkage behavior. To protect the structures, build over the expansive soil, from damage and to increase its design life, it is necessary to modify the properties of virgin soil.

Experimental studies have been carried out in the laboratory by adding admixtures such as Bagasse ash and hydrated lime to the expansive soils at different proportions. The expansive soils tested are collected from Kattur, Kancheepuram district, Tamilnadu, India. The additives used have been chosen, focusing on "waste reduction, economy, and its eco-friendly nature".

Bagasse ash, a fibrous waste product, obtained from sugarrefining industry, is easily available at a lower cost poses serious threat to the environment and needs attention on its safe disposal. For each 10 tonnes of sugarcane crushed, a sugar factory produces nearly 3 tonnes of wet bagasse. Since bagasse is a by-product of the cane sugar industry, the quantity of production in each country is in line with the quantity of sugarcane produced.
Sugar-cane bagasse is a fibrous waste product of the sugar refining industry, along with ethanol vapour. In this paper, Bagasse ash has been chemically and physically characterized, in order to evaluate the possibility of their use in the industry. Since the chemical composition of bagasse ash contains $\mathrm{SiO}$, $\mathrm{Al} 2 \mathrm{O} 3 \& \mathrm{CaO}$ and it chemically reacts with water and produces a cementitious bond between the soil particles.

Bagasse ash is effectively used along hydrated lime, which aids in improving the engineering properties of expansive soil. Lime has a number of effects when added into soil, which can be generally categorized as soil drying, soil modification, and soil stabilization.

When lime comes into contact with a substance containing soluble silicates and aluminates such as clay, it forms hydrated calcium aluminates and calcium silicates. As with Bagasse Ash, this gives rise to a true bond upon crystallization, called a pozzolanic reaction, this bonding process brings about improved resistance to frost and a distinct increase in the soil's compressive strength.

\section{EXPERIMENTAL STUDY}

\subsection{Materials}

Expansive soil is collected from Kattur village, Kanchipuram district. Bagasse ash is collected during cleaning operation of boiler from Sakthi Sugar Factory, Sathyamangalam, Erode-Dt, Tamilnadu. Hydrated lime is collected from Venkatachalapathy Limestone Industries. 
The basic properties of materials used in the paper are presented below.

\section{Soil}

Liquid limit, $\mathrm{W}_{\mathrm{L}}=62 \%$; Plastic limit, $\mathrm{W}_{\mathrm{P}}=20 \%$; shrinkage limit $\mathrm{W}_{\mathrm{S}}=10.8 \%$; IS Classification $\mathrm{CH}$ (Clay of high compressibility); Optimum moisture content $\mathrm{OMC}=22.65 \%$; Maximum dry density, $\mathrm{MDD}=1.582 \mathrm{~g} / \mathrm{cc} ; \mathrm{FSI}=72.7 \%$.

\section{Bagasse Ash (B)}

The sugarcane bagasse consists of approximately $50 \%$ of cellulose, $25 \%$ of hemicellulose and $25 \%$ of lignin. The general composition of Bagasse Ash are $\mathrm{SiO}_{2}=78.34 \%, \mathrm{Al}_{2}=$ $8.55 \%, \mathrm{Fe}_{2} \mathrm{O}=3.61 \%, \mathrm{CaO}=2.15 \%, \mathrm{Na}_{2} \mathrm{O}=0.12 \%$, Loss in ignition $=0.42 \%$.

\section{Lime (L)}

The chemical compositions of hydrated lime used are given Assay $=95 \%, \mathrm{Ca}(\mathrm{OH})_{2}=74.10 \%$, chloride $=0.01 \%$, Sulphate $=$ $0.2 \%$, Arsenic $=0.0004 \%$, Insoluble matter $=1 \%$.

\subsection{Admixture Proportions and Test Conducted}

The proportions of Bagasse ash and Lime used along with the soil in the study are $2 \%, 4 \%, 6 \%$ and $1 \%, 2 \%, 3 \%$ respectively. The following tests were conducted on the soil samples mixed at different proportions $-1 \% \mathrm{~L}: 2 \%, 4 \%, 6 \%$ BA; $2 \%$ L: $2 \%, 4 \%, 6 \%$ BA; $3 \%$ L: $2 \%, 4 \%, 6 \%$ BA. The liquid limit and plastic limit tests were conducted as per IS: 2720 (Part 5) - 1985. Heavy compaction test was carried out according to IS: 2720(Part 8)-1983. Unconfined compressive strength (UCS) tests were conducted at OMC and MDD as per IS: 2720(Part 10) - 1991 for 7 and 14 days. Oedometer tests were carried out as per IS: 2720 (Part 15) 1986. Cation Exchange Capacity CEC tests were conducted as per IS: 2720 (Part 24) - 1976

\section{RESULTS AND DISCUSSIONS}

Atterberg's limits, Proctor compaction, Unconfined compressive strength, Oedometer tests, Cation Exchange Capacity tests were conducted with different percentages of Bagasse Ash and hydrated lime (as mentioned above) as admixtures in expansive soil for finding optimum percentage of mixes.

\subsection{Atterberg Limits}

From the Fig.1, it is observed that as the increases in Bagasse ash content with $1 \%$ Lime, there is a marked reduction in liquid limit whereas plastic limit is increases. From this, it can be deduced that the flow characteristics soil sample are gradually decreasing from $62 \%$ to lowest value of $55.7 \%$ with increase in Bagasse Ash content with $1 \%$ Lime and plastic limit of these mixes are increases from $20 \%$ to maximum of $35.61 \%$.

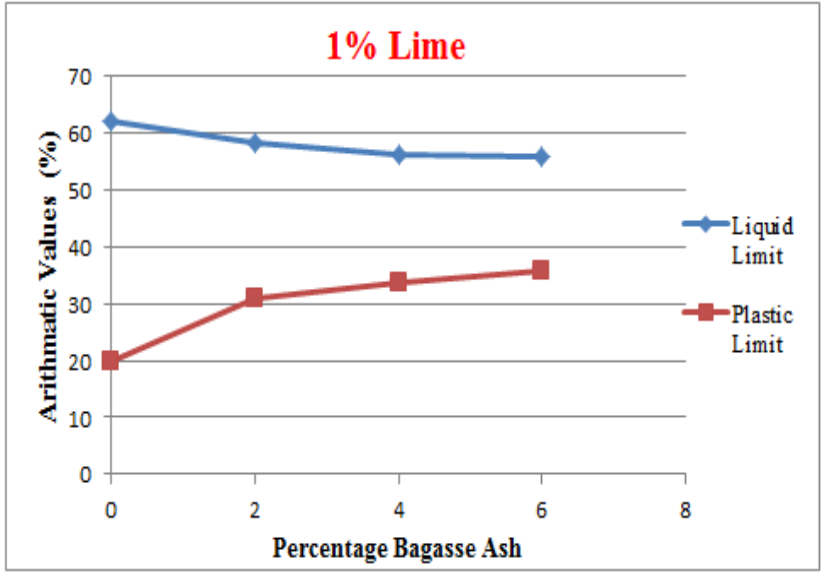

Fig-1: Liquid \& Plastic limit for virgin soil and mixes of $2 \mathrm{~B}+1 \mathrm{~L}, 4 \mathrm{~B}+1 \mathrm{~L}, 6 \mathrm{~B}+1 \mathrm{~L}$.

From the Fig.2, the liquid limit value decreases from $62 \%$ to $47.9 \%$ with increases in Bagasse ash content with $2 \%$ Lime as it deduced that the flow characteristics soil sample and plastic limit of these mixes are increases from $20 \%$ to maximum of $31.41 \%$.

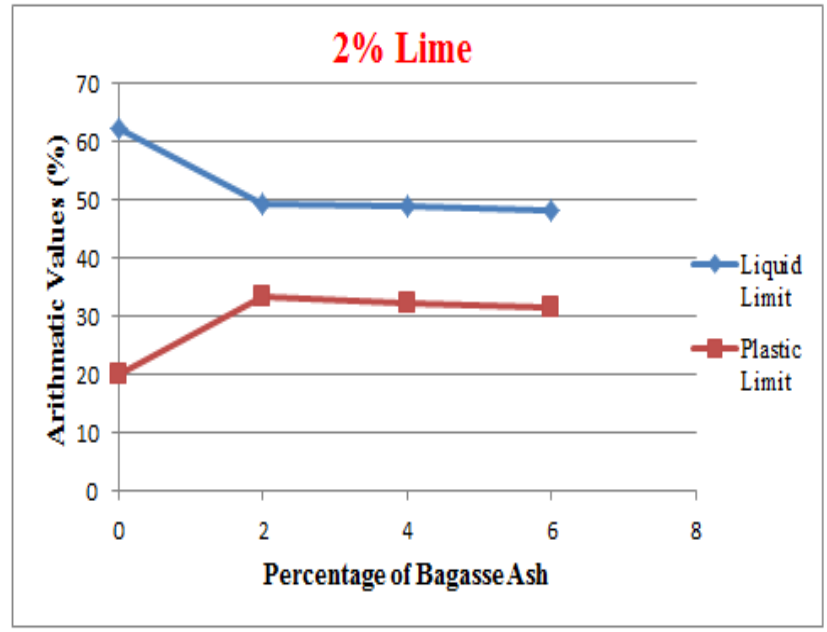

Fig-2: Liquid \& Plastic limit for virgin soil and mixes of $2 \mathrm{~B}+2 \mathrm{~L}, 4 \mathrm{~B}+2 \mathrm{~L}, 6 \mathrm{~B}+2 \mathrm{~L}$.

From the Fig.3, the liquid limit value decreases from $62 \%$ to 44.8\% with increases in Bagasse ash content with 3\% Lime and plastic limit of these mixes are increases from $20 \%$ to maximum of $32.2 \%$. 


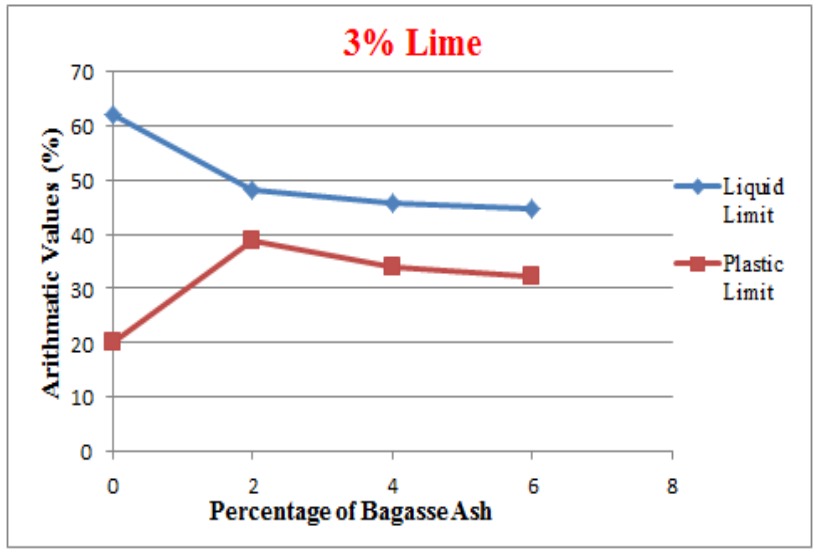

Fig-3: Liquid \& Plastic limit for virgin soil and mixes of $2 \mathrm{~B}+3 \mathrm{~L}, 4 \mathrm{~B}+3 \mathrm{~L}, 6 \mathrm{~B}+3 \mathrm{~L}$.

The increase of plastic limit implies that Bagasse ash and Lime treated soil required more water to change it plastic state to semisolid state. This change of Atterberg limit is due to the cation exchange reaction and flocculation-aggregation for presence of more amount of Bagasse ash - Lime content, which reduces plasticity index of soil. A reduction in plasticity index causes a significant decrease in swell potential and removal of some water that can be absorbed by clay minerals. From the test result of Atterberg limit, changing of soil grain size due to the addition of Bagasse ash (2, 4 and 6\%) with Lime (1,2 and 3\%) can be illustrated by plasticity chart. The effect of Bagasse ash and Lime on the particle size of soil is shown in Fig. 4.

The below Fig.4 illustrate that initially the soil was clay with High plasticity. For the increasing amount Bagasse ash and Lime content, the soil class shifts to silt properties (due to the increase in particle sizes for the agglomeration of clay particles with Bagasse ash and Lime).

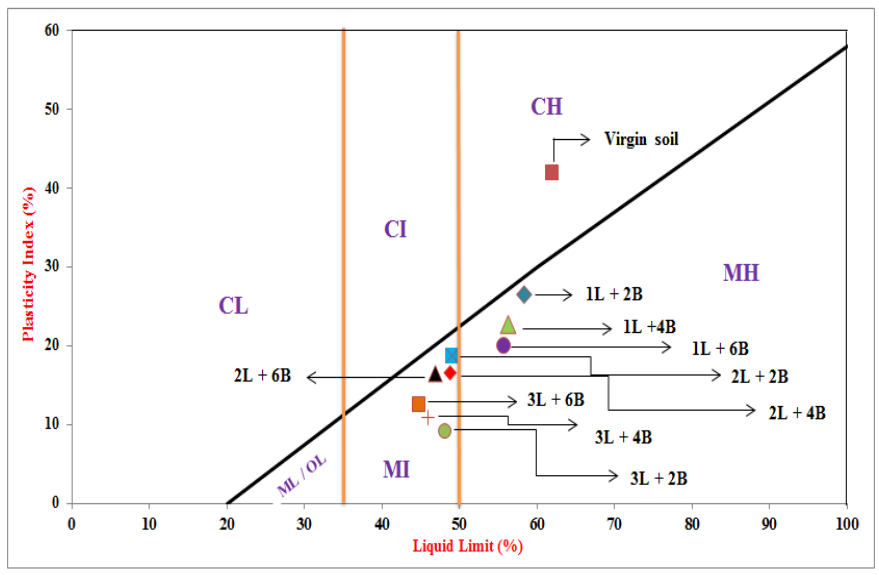

Fig-4: Plasticity chart showing the Virgin and Bagasse Ash Lime treated soil

\subsection{Compaction Characteristics}

The variation of optimum moisture content and maximum dry density for Bagasse ash + Lime treated and untreated soil is shown in Fig. 5 \& Fig.6. This Figure represents the maximum dry density of soil decreases gradually with an increase of Bagasse ash content, with Lime.

The reduction in dry density is a result of flocculation and agglomeration of fine grained soil particles which occupies larger space leading to a corresponding drop in maximum dry density. It is also the result of initial coating of soils by Bagasse ash \& Lime to form larger aggregate, which consequently occupy larger spaces.

On the other hand, the optimum moisture content of soil increases with increases in Bagasse ssh \& Lime content, because these admixes were finer than the soil. The more fines the more surface area, so more water is required to provide well lubrication.

These mixes $(\mathrm{B}+\mathrm{L})$ also decrease the quantity of free silt and clay fraction, forming coarser materials, which occupy larger spaces for retaining water. The increase of water content was also attributed by the pozzolanic reaction of the mixes with the soil.

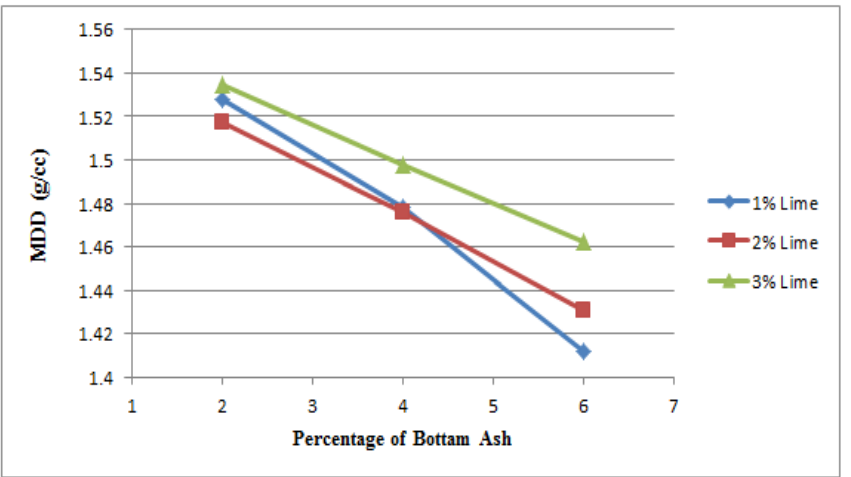

Fig-5: Variation of maximum dry density with different mixes of B \& L content

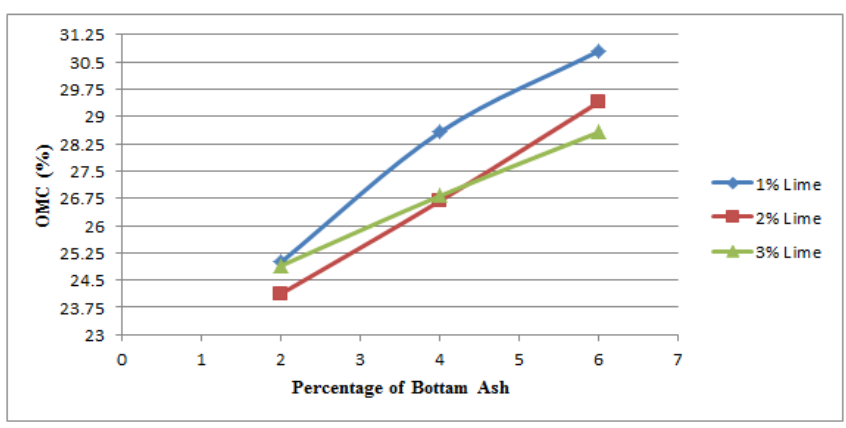

Fig-6: Variation of optimum moisture content with different mixes of B \& L content 


\subsection{Unconfined Compressive Strength}

The test result of unconfined compressive strength is shown in Fig.7, Fig.8 \& Fig.9. This Fig. illustrates the stress-strain behavior of original and $\mathrm{B}+\mathrm{L}$ treated soil under vertical load. Initially the stress is rapidly increases with the increase of strain. After attaining the peak stress, it decreases with the increase of strain for all the combination of mixes and soil. The entire specimen prepared with $1 \%$ Lime and 2, 4, 6\% Bagasse ash shows shear failure after observing the failure plane of specimens. Apart from this, the percentages of Lime $(2,3 \%)$ with Bagasse ash $(2,4$, and $6 \%)$ were shows brittle failure, which implies that the samples are becoming hardened from its original ductile nature.

From the Fig. 7, the variation of unconfined compressive strength for soil with $1 \%$ Lime and 2, 4, 6\% of Bagasse ashes at 7 days and 14 days curing are shown. It is observed that the mix $(2 \mathrm{~B}+1 \mathrm{~L})$ gives higher value of $81.38 \mathrm{kPa} \& 103.9 \mathrm{kPa}$ at 7 days and 14 days respectively, whereas the soil UCS value is $76.48 \mathrm{kPa}$.

Similarly, the drop in the strength for other mixes $(4 \mathrm{~B}+1 \mathrm{~L})$; $(6 \mathrm{~B}+1 \mathrm{~L})$ are also seen due to carbonation reactions which occurs due to the presence of excess lime to react with insufficient silica and alumina present in Bagasse ashexpansive soil mixes.

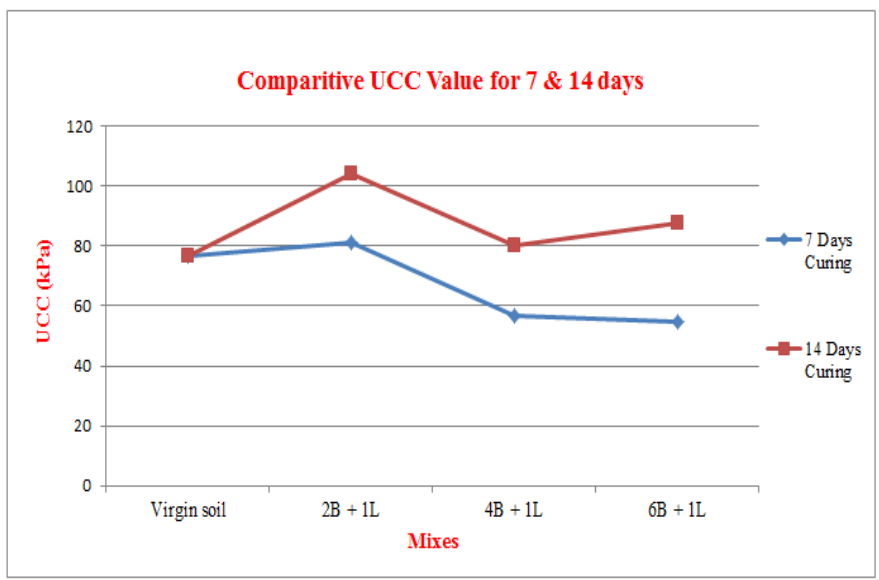

Fig-7: Variation of UCC value with different mixes of B \& L content at 7 days and 14 days

Similarly, from the Fig. 8, the variation of unconfined compressive strength for soil with $2 \%$ Lime and 2, 4, $6 \%$ of Bagasse Ash at 7 days and 14 days curing are shown. It is observed that all the mixes gives higher value of $446.2 \mathrm{kPa}$, $438.3 \mathrm{kPa}, 299 \mathrm{kPa}, 720.7 \mathrm{kPa}, 505 \mathrm{kPa}, 402 \mathrm{kPa}$ at 7 days and 14 days respectively, compared to the soil UCS values is $76.48 \mathrm{kPa}$.

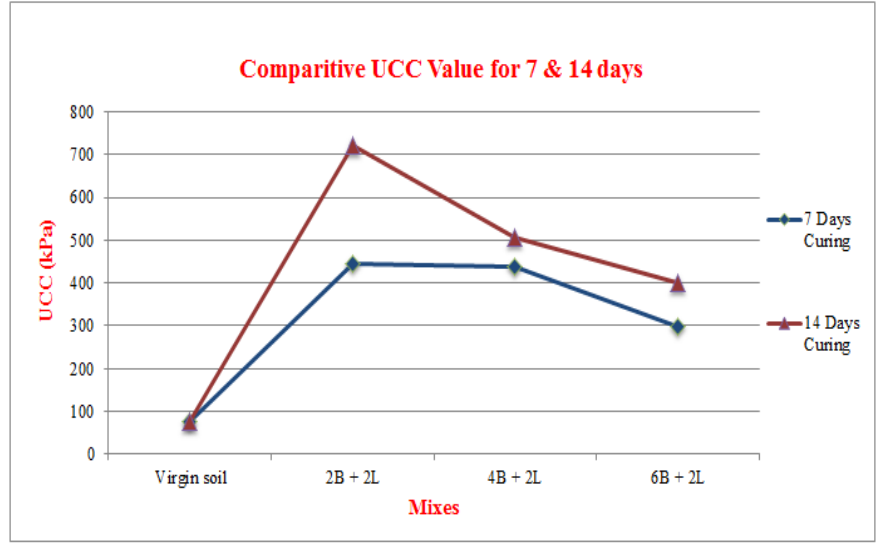

Fig-8: Variation of UCC value with different mixes of B \& L content at 7 days and 14 days

From the Fig. 9, the variation of unconfined compressive strength for soil with 3\% Lime and 2, 4, 6\% of Bagasse Ash at 7 days and 14 days curing are shown. It is observed that all the mixes gives higher value of $632.4 \mathrm{kPa}, 703.4 \mathrm{kPa}, 588.3 \mathrm{kPa}$, $764.8 \mathrm{kPa}, 990.4 \mathrm{kPa}, 632.4 \mathrm{kPa}$ at 7 days and 14 days respectively, compared to the soil UCS values is $76.48 \mathrm{kPa}$.

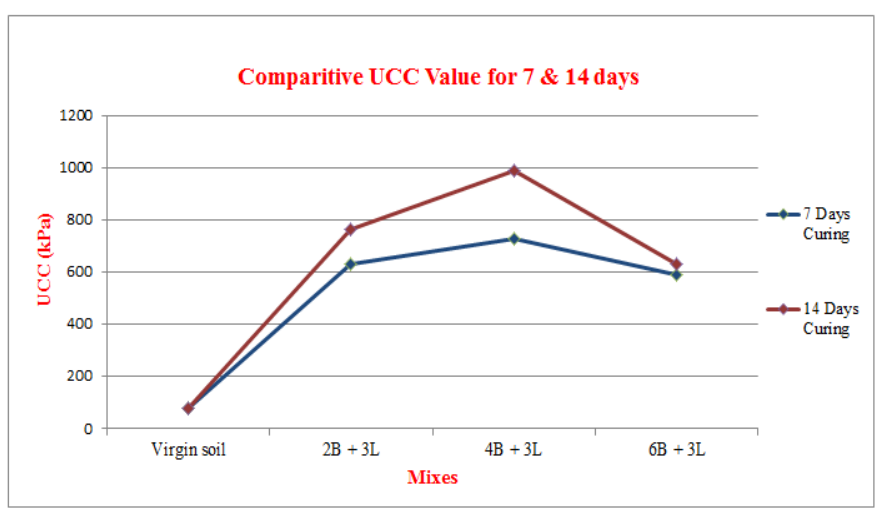

Fig-9: Variation of UCC value with different mixes of B \& L content at 7 days and 14 days

The peak value was found in the mixes of $2 \mathrm{~B}+1 \mathrm{~L}, 2 \mathrm{~B}+2 \mathrm{~L}$, $4 \mathrm{~B}+3 \mathrm{~L}$ whereas, for other mixes, the strength is decreased as compared to the peak value mixes, since due to carbonation reactions which occurs due to the presence of excess lime to react with insufficient silica and alumina present in Bagasse ash-expansive soil mixes.

\subsection{Cationic Exchange Capacity}

The test result of cationic exchange capacity is shown in TABLE I. This table illustrates the change of expansive soil mineral type from Montmorillonite to Halloysite and Illite. These may be due to molecular change in their structure, due to pozzolanic activity and cationic exchange capacity happens between the admixtures with soil. 
Table -1: Cationic Exchange Capacity for all mixes

\begin{tabular}{|l|l|}
\hline Mixes & $\begin{array}{l}\text { Cationic Exchange } \\
\text { Capacity } \\
\text { (meq/100g) }\end{array}$ \\
\hline Virgin Soil & 82.28 \\
\hline 1L+2B & 51.39 \\
\hline 1L+4B & 40.67 \\
\hline 1L+6B & 35.45 \\
\hline 2L+2B & 27.07 \\
\hline 2L+4B & 25.87 \\
\hline 2L+6B & 24.55 \\
\hline 3L+2B & 16.58 \\
\hline 3L+4B & 18.20 \\
\hline 3L+6B & 17.38 \\
\hline & \\
\hline
\end{tabular}

\subsection{Consolidation Characteristics}

In this study one dimensional consolidation test were performed to determine the consolidation characteristics of untreated soil and treated mixes. The corresponding consolidation curves are shown below. The variation of Coefficient of Consolidation (Cv) Compression index (Cc), Expansion Index (Ce), Recompression Index (Cr) for untreated and treated samples were shown below,

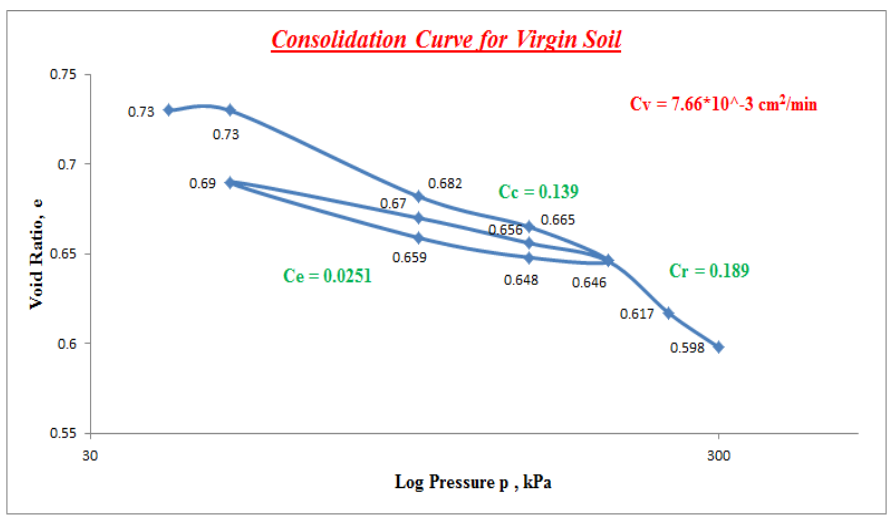

Fig-10: Consolidation curve for Virgin soil

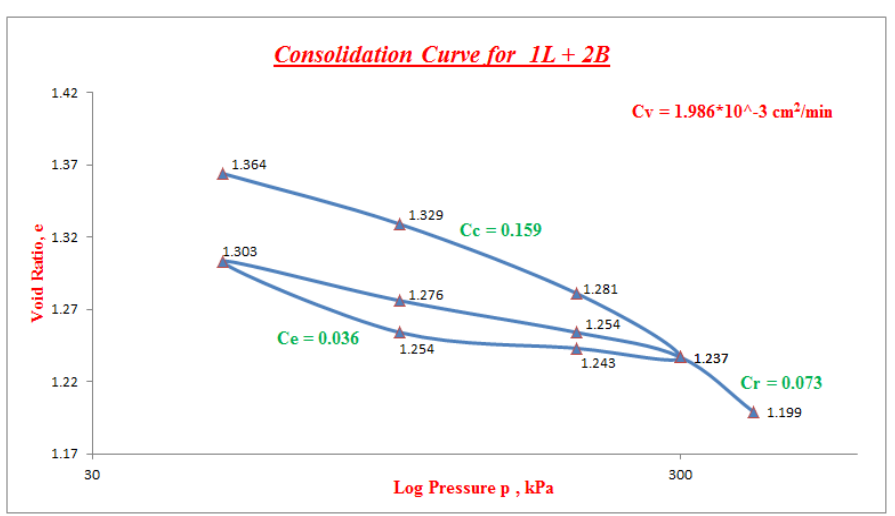

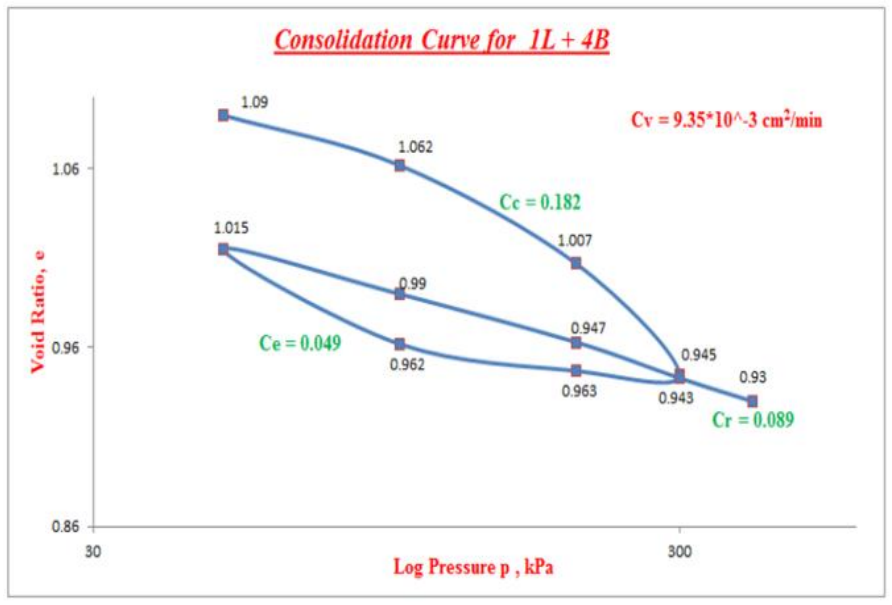

Fig-12: Consolidation curve for $1 \mathrm{~L}+4 \mathrm{~B}$ mix

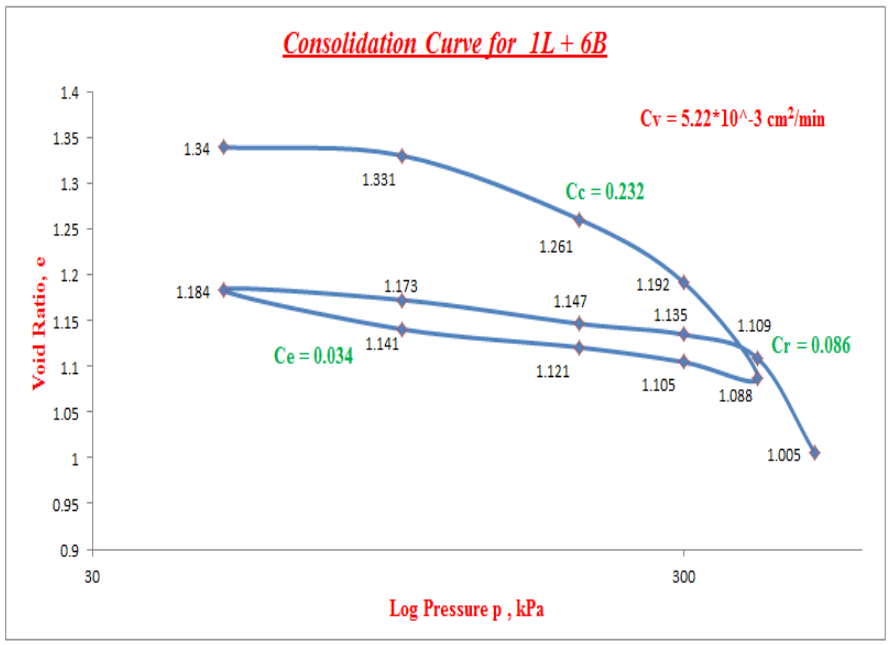

Fig-13: Consolidation curve for $1 \mathrm{~L}+6 \mathrm{~B}$ mix

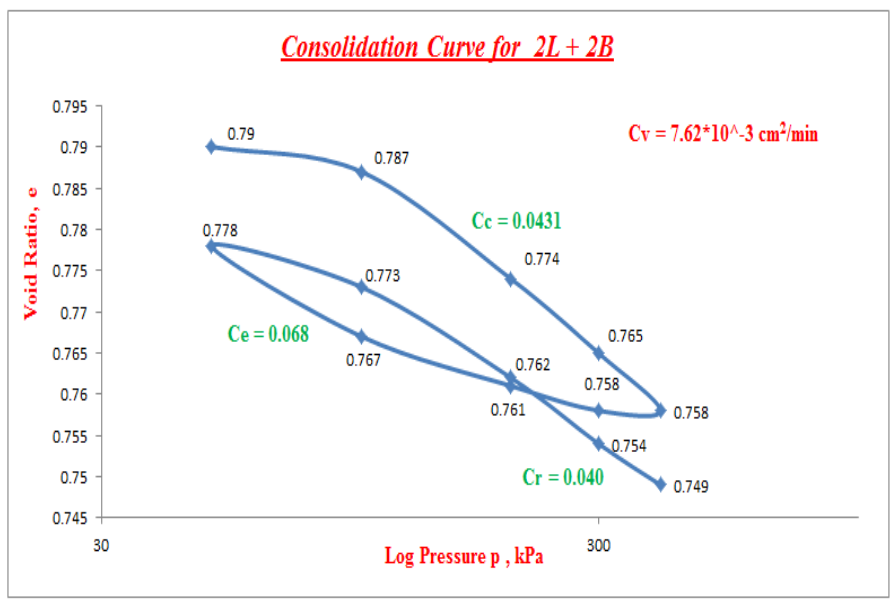

Fig-14: Consolidation curve for $2 \mathrm{~L}+2 \mathrm{~B}$ mix

Fig-11: Consolidation curve for $1 \mathrm{~L}+2 \mathrm{~B}$ mix 


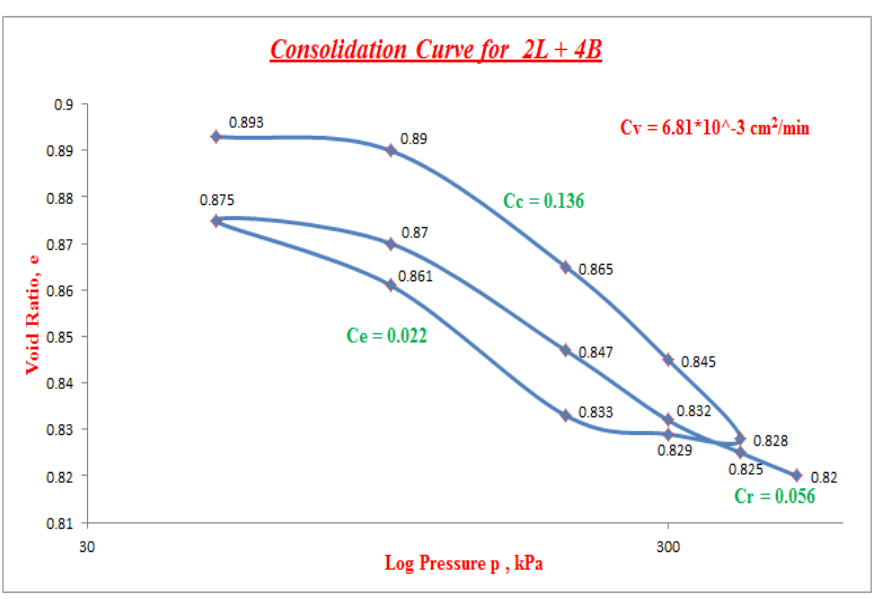

Fig-15: Consolidation curve for $2 \mathrm{~L}+4 \mathrm{~B}$ mix

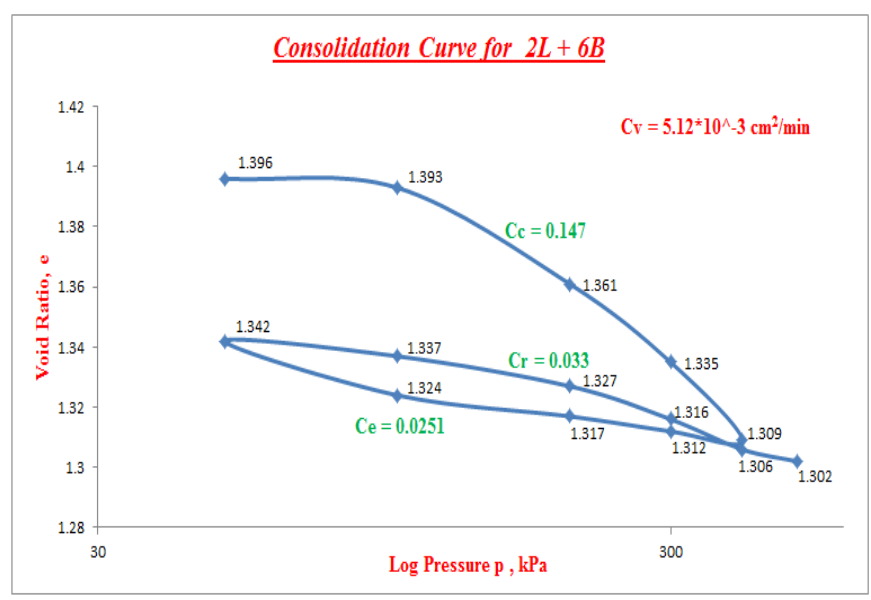

Fig-16: Consolidation curve for $2 \mathrm{~L}+6 \mathrm{~B}$ mix

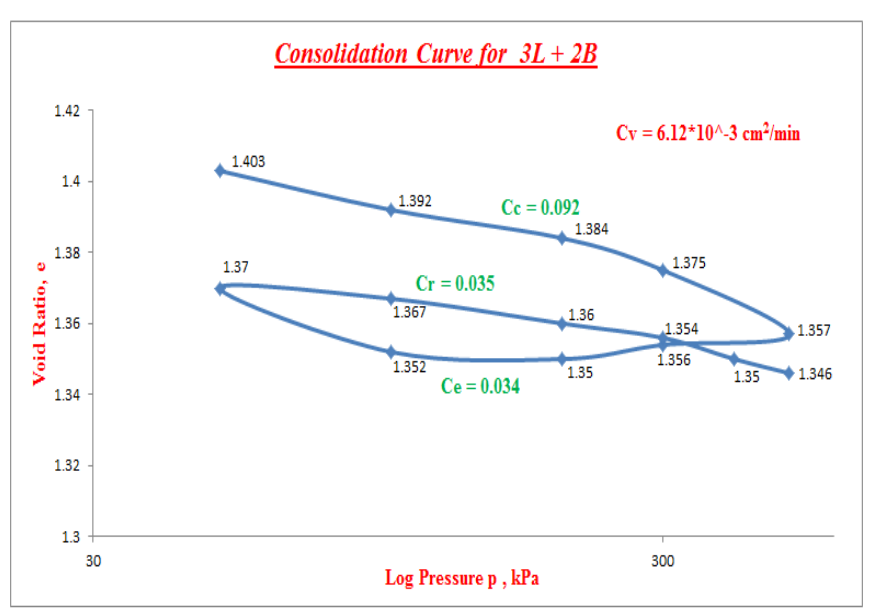

Fig-17: Consolidation curve for $3 \mathrm{~L}+2 \mathrm{~B}$ mix

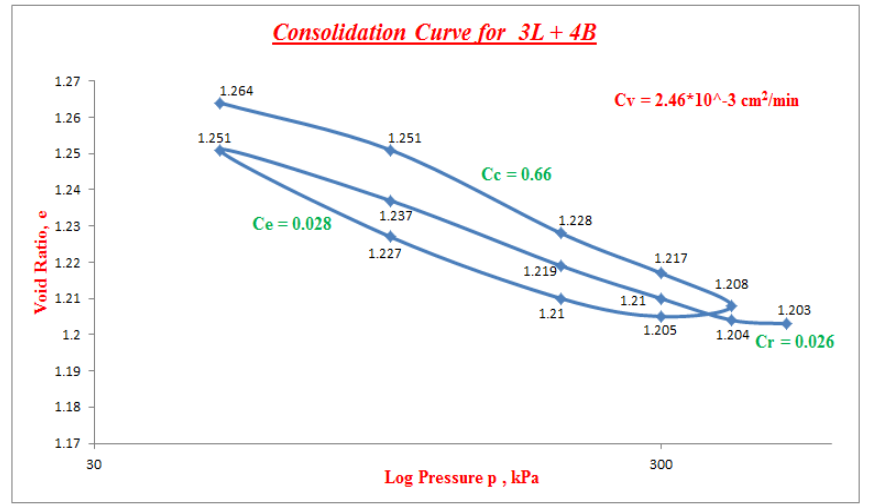

Fig-18: Consolidation curve for $3 \mathrm{~L}+4 \mathrm{~B}$ mix

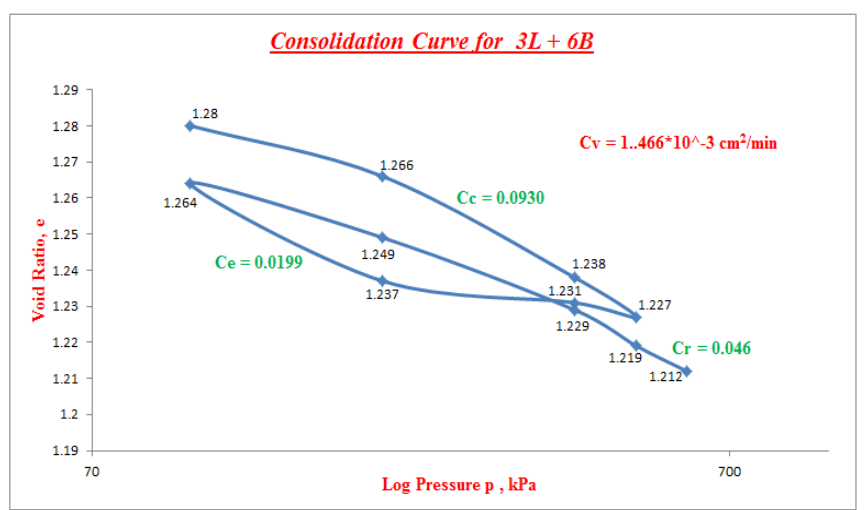

Fig-19: Consolidation curve for $3 \mathrm{~L}+6 \mathrm{~B}$ mix

From the above graph, it is observed that the value of $\mathrm{Cv}$ decreases for mixes as compared to the virgin soil value. The lowest value of $\mathrm{Cv}$ is attained by the mix combination of $3 \mathrm{~L}+$ $6 \mathrm{~B}$ is $1.466 \times 10-3 \mathrm{~cm} 2 / \mathrm{min}$ as compared to virgin soil value as $7.66 \times 10-3 \mathrm{~cm} 2 / \mathrm{min}$. The value of $\mathrm{Cc}$ also decreased for all mixes as compared to of virgin soil value.

As stated in Fig., the lowest value is 0.0431 associated with the mix combination of $2 \mathrm{~L}+2 \mathrm{~B}$ as compared to 0.139 . As like, the value of $\mathrm{Ce}$ and $\mathrm{Cr}$ are also decreased with the mix combination of $3 \mathrm{~L}+6 \mathrm{~B}$ as $0.019,0.046$ as compared to virgin soil value as $0.0251 \& 0.189$ respectively. Hence the mixes like $3 \mathrm{~L}+6 \mathrm{~B}$ yield better results, even though all the mixes combination gave best results in term of $\mathrm{Cv}, \mathrm{Cc}, \mathrm{Ce}, \mathrm{Cr}$.

This decrease in consolidation parameter as listed above implies that there could be a result of increased formation of pozzolanic products within the pore spaces of soil from physicochemical changes (Osinubi et al. 2006) which leads to a reduction in those values. Since all mixes are not linearly shows decrement in their value, that may because of Bagasse Ash \& Lime content exceeds the quantity required for the Soil - Bagasse ash - Lime reaction, they will be filled between the voids of the soil. 


\subsection{Volume Change Behavior}

From the Oedometer test, the percentage volume changes are observed for all mixes and are shown in following graph.

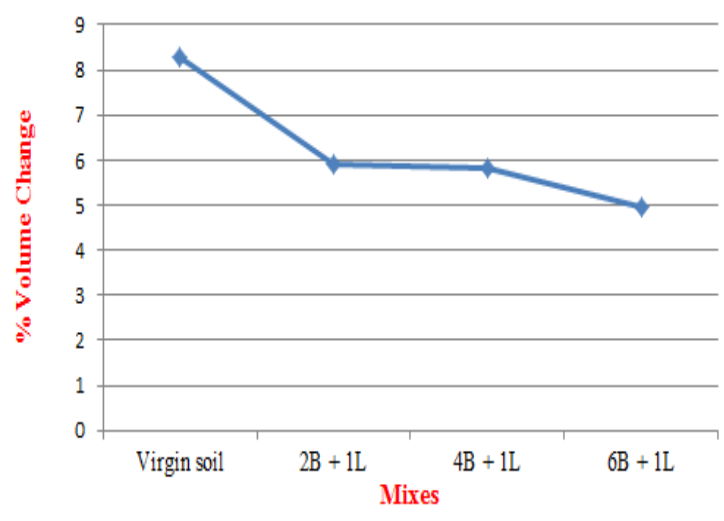

Fig-20: Comparative $\%$ volume change for Virgin soil and $.1 \%$ Lime, Bagasse Ash of 2,4,6\% treated soil.

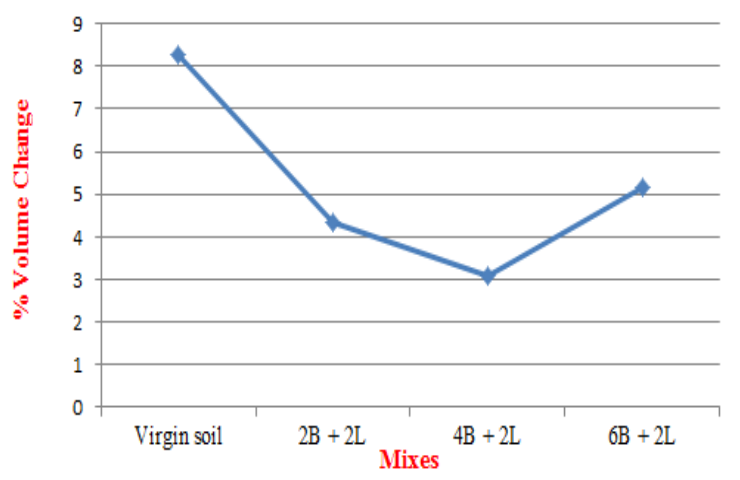

Fig-21: Comparative \% volume change for Virgin soil and 2\% Lime, Bagasse Ash of 2, 4, and 6\% treated soil.

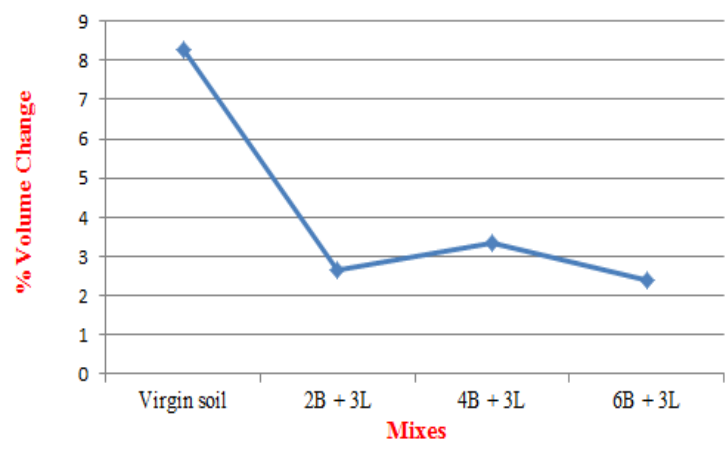

Fig-22: Comparative \% volume change for Virgin soil and 3\% Lime, Bagasse Ash of 2, 4, and 6\% treated soil.
From the above chart, it is compared with virgin soil's percentage volume change $8.27 \%$ with all mixes of Lime and Bagasse ash. It is observed that all mixes shows decrement in their percentage volume change as compare with virgin soil. The better results ascertained from the mix of $2 \mathrm{~L}+2 \mathrm{~B}$ as $1.36 \%$ and next is followed by the mix $3 \mathrm{~L}+6 \mathrm{~B}, 3 \mathrm{~L}+2 \mathrm{~B}$ shows the value of $2.39 \% \& 2.67 \%$ respectively. This results conforms that the sample become harden, such that it possess less settlement in site, when the soil was mixed with these percentage as compare to of virgin soil strata.

\section{CONCLUSIONS}

A study has been conducted to investigate the fundamental properties such as consistency, compaction, compressive strength, cationic exchange capacity, consolidation characteristics and percentage volume change of untreated and Bagasse ash - Lime treated soil. It can be concluded that there is an improvement of all the geotechnical properties of Bagasse ash - Lime treated soil. The following conclusions, based on the test results in this study, are drawn.

- A series of liquid and plastic limit tests were performed on the untreated and Bagasse ash - Lime treated soil samples. It is observed that as the increases in Bagasse ash content with Lime, there is a marked reduction in liquid limit whereas plastic limit is increases. From this, it can be deduced that the flow characteristics soil sample are gradually decreasing and the increase of plastic limit implies that Bagasse ash and Lime treated soil required more water to change it plastic state to semisolid state.

- This change of Atterberg's limit is due to the cation exchange reaction and flocculation-aggregation for presence of more amount of Bagasse ash - Lime, which reduces plasticity index of soil. A reduction in plasticity index causes a significant decrease in swell potential and removal of some water that can be absorbed by clay minerals.

- The pozzolanic behavior of Bagasse ash and Lime makes the treated soil coarser than original soil samples due to the agglomerations of Bagasse ash and Lime and soil particles. This improvement changes the soil from clay properties to silt properties.

- The maximum dry density of soil decreased with the addition of Bagasse ash - Lime and value of optimum moisture content mixes treated soil increased because of the pozzolanic action of Bagasse ash - Lime and soil, which needs more water.

- The unconfined compressive strength was obtained for all mixes. The peak value was found in the mixes of $2 \mathrm{~B}+1 \mathrm{~L}, 2 \mathrm{~B}+2 \mathrm{~L}, 4 \mathrm{~B}+3 \mathrm{~L}$ whereas, for other mixes, the strength is decreased as compared to the peak value mixes, since due to carbonation reactions which occurs due to the presence of excess lime to react 
with insufficient silica and alumina present in Bagasse ash - expansive soil mixes.

- From the cationic exchange capacity test, the change of expansive soil mineral type from Montmorillonite to Halloysite and Illite due to molecular change in their structure, due to pozzolanic activity and cationic exchange capacity happens between the admixtures with soil. This leads to interlayer swelling type of mineral to non-interlayer swelling type of soil mineral.

- From the consolidation test result, it can be concluded that the values of co-efficient of consolidation, compression index, expansion index, recompression index decreased with the increases of Bagasse ash and Lime content. All the mixes shows best results, but better decrement given by the mix of $3 \mathrm{~L}+6 \mathrm{~B}$.

- The percentages of volume change are also observed from the consolidation test results. As like above, the best results given by all mixes, but the better results associated with the mix proportion of $3 \mathrm{~L}+6 \mathrm{~B}, 3 \mathrm{~L}+$ 2B.

From overall observation, it is concluded that the optimum combination of Bagasse ash and Lime content, as in the case of all the tests performed under this study are $3 \mathrm{~L}+6 \mathrm{~B}, 3 \mathrm{~L}+2 \mathrm{~B}$, $2 \mathrm{~L}+2 \mathrm{~B}, 3 \mathrm{~L}+4 \mathrm{~B}$. This results conforms that the sample become harden, such that it possess less settlement or damage to the building in site, when the soil was mixed with these percentage as compare to of virgin soil strata.

\section{REFERENCES}

[1]. Ahmad, S.F. and Shaikh, Z. (1992), 'Portland - pozzolana from sugar cane bagasse ash. In: Hill, N., Holmes, S. and Mather, D. (Eds), Lime and Other Alternative Cement' Intermediate Technology Publications, London, pp.172-179. [2]. Al-Rawas A.A., Hago A.W., Al-Sarmi H. (2005), ' Effect of lime, cement and Saroo (artificial pozzolan) on the swelling potential of an expansive soil from Oman, Building and Environment' 40(5), 681-687.

[3]. Arash Barazesh, Hamidreza Saba, Mehdi Gharib (2012),'The Effect of Adding Iron Powder on Atterberg Limits of Clay Soils', International Research Journal of Applied and Basic Sciences, ISSN 2251-838X / Vol, 3 (11): 2349-2354, 2012.

[4]. Bilba, K., Arsene, M.A. and Ouensanga, O. (2003), 'Sugar cane bagasse fibre reinforced cement composites part I', Vol. 25, No. 1, pp. 91-96.

[5]. Bulbul Ahmed, Md. Abdul Alim, Md. Abu Sayeed (2013),'Improvement of soil strength using cement and lime admixtures', Earth Science 2013; 2(6): 139-144

[6]. Clara H., Handy R.L. (1963), 'Characteristics of lime retention by montmorillonite clays' Highway Research Record,29, 55-69.
[7]. D. N. John, and J. M. Debora, (1992), "Expansive SoilsProblems and practice in foundation and pavement engineering”, John Wiley \& Sons. Inc., New York.

[8]. Grytan Sarkar, MD.Rafiqul Islam, Muhammed Alamgir, MD.Rokonuzzaman(2012), 'Study on the Geotechnical Properties of Cement based Composite Fine-grained Soil', International Journal of Advanced Structures and Geotechnical Engineering', ISSN 2319-5347, Vol. 01, No. 02, October 2012.

[9]. IS: 2720(Part 40), 1977, 'Code of practise for Determination of Free swell', BIS, New Delhi.

[10]. IS: 2720(Part3/sec-1) 1980, 'Code of practise for Determination of specific gravity, BIS, New Delhi.

[11]. IS: 2720(Part 5) 1970, 'Code of practise for Determination of liquid \& plastic limit', BIS, New Delhi.

[12]. IS: 2720 (Part 7) 1972, 'Code of practise for Determination of shrinkage factors', BIS, New Delhi.

[13]. IS: 2720 (Part 7) 1980, 'Determination of moisture content-dry density relation using lite compaction', BIS, New Delhi.

[14]. IS: 2720 (Part 2) 1973, 'Code of practise for Determination of water content, BIS, New Delhi.

[15]. IS: 2720 (Part 10) 1970, 'Code of practise for Determination of Unconfined Compressive Strength', BIS, New Delhi.

[16]. IS: 2720 (Part 15) 1986, 'Code of practise for Determination of Consolidation properties, BIS, New Delhi.

[17]. IS: 2720 (Part 24) 1976, 'Code of practise for Determination of Cationic Exchange Capacity, BIS, New Delhi.

[18]. Ingles O. G., Metcalf J. A., Soil Stabilization principles and Practice, Butter worths Sydney, 1972, p. 370 - 375.

[19]. K.V. Madurwar, P.P. Dahale, A.N.Burile (2013),' Comparative Study of Black Cotton Soil Stabilization with RBI Grade 81 and Sodium Silicate', International Journal of Innovative Research in Science, Engineering and Technology, Vol. 2, Issue 2, February 2013.

[20]. Misari, S.M., Busari, L.D. and Agboire, S. (1998), 'Current Status of Sugar Cane Research and Development in Nigeria', Proceedings of National Co-ordinated Research Programme on Sugar Cane, NCRI, Badeggi, pp. 2-12.

[21]. Mir Sohail Ali and Shubhada Sunil Koranne (2011),'Performance Analysis of Expansive Soil Treated With Stone Dust and Fly Ash', EDJE, Vol. 16 [2011], Bund.I

[22]. Osinubi, K.J. and Mohammed, M.A. (2005), 'Potentials of bagasse ash as pozzolans.' Procedings. of the Nigerian Material Congress 2005 (NIMACON 2005), 17 - 19 November, Zaria. Nigeria, pp $41-45$.

[23]. Paya,' J., Monzo,' J., Borrachero, M.V., Di'az, P. and Ordon ez, L.M (2002), 'Sugarcane bagasse ash (SCBA): Studies on its properties for reusing in concrete production', Journal of Chemical Technology and Biotechnology. 77: 321325.

[24]. Ramadas, T.L. Kumar, N. Darga, Aparna, G.(2010), 'Swelling and Strength Characteristics of Expansive Soil 
Treated with Stone Dust and Fly Ash', Indian Geotechnical Conference - 2010.

[25]. Sharma,R.S. ,PhaniKumar,B.R., and Rao,B.V.(2008) "Engineering behavior of a remolded expansive clay blended with lime, calcium chloride and rice -husk ash," Journal of Materials in Civil Engineering,Vol.20(8),pp 509-515.

[26]. Sabat, A.K., and Nanda, R.P. (2011) "Effect of marble dust on strength and durability of rice husk ash stabilised expansive soil," International journal of Civil and Structural Engineering, Vol.1 (4), pp 939 -948.

[27]. Solomon, S. (2011) "The Indian Sugar Industry: An Overview," Sugar Tech, Vol.13 (4), pp 255-265.

[28]. Tonoz, M.C., Ulusay, R. and Gokceoglu, C. (2004). "Effect of Lime Stabilization on Engineering Properties of Expansive Ankara Clay", Lnes (Eds: Hack R. et al.) Springer-Verlag Berlin, pp. 466-474. 